\title{
Medical Treatment in Covid-19: Changes in Post-treatment Laboratory Results and CT Findings
}

\author{
(iD) İnan Korkmaz ${ }^{1}$, (D) Nursel Dikmen² \\ ${ }^{1}$ Asst. Prof.Mustafa Kemal University, Faculty of Medicine, Department of Radiology, Hatay, Turkey \\ ${ }^{2}$ Asst. Prof. Mustafa Kemal University, Faculty of Medicine, Department of Chest Diseases, Hatay, Turkey \\ Öz
}

\section{Covid-19'da Tıbbi Tedavi: Tedavi Sonrası Laboratuvar Sonuçlarında ve BT Bulgularında Değișiklikler}

Amaç: Günümüzde, Koronavirüs hastalığı 2019'un semptomları, görüntüleme özellikleri ve laboratuvar bulguları bilinmektedir ancak hastalığın tedavisi netlik kazanmamıștır. Bu çalıșmada, invaziv mekanik ventilasyona ihtiyaç duymayan hastalarda favipiravirin etkinliğini tedavi sonrası laboratuvar ve bilgisayarlı tomografi bulgularındaki değișimleri, tedavi kılavuzundan çıkarılan hidroksiklorokin ile karșılaștırarak incelemeyi amaçladık.

Gereç ve Yöntem: Çalıșmamızda Koronavirüs hastalığı 2019 tanısı konulan ve hidroksiklorokin ve favipiravir ile tedavi edilen 49 hasta incelendi. Hastalar tedavi șekillerine göre 3 gruba ayrıldı. Bu 3 gruptaki hastaların tedavi öncesi ve sonrası laboratuvar bulgularındaki ve bilgisayarlı tomografi görüntülemesindeki değișiklikler incelendi.

Bulgular: Gruplarda, toraks bilgisayarlı tomografi tetkikinde izlenen lezyon paternlerinin oranları ve türleri arasında istatistiksel olarak anlamlı bir fark yoktu. Her bir grupta lezyon paterni olarak en sık hidroksiklorokin grubunda 18 hastada (\%81.8), favipiravir grubunda 7 hastada (\%70) ve hidroksiklorokin+favipiravir grubunda 10 hastada (\%58.8) buzlu cam dansitesi+konsolidasyon varlığı izlendi. Her 3 grupta da C-reaktif protein, ferritin, fibrinojen değerlerinde ve bilgisayarlı tomografi skorlarında tedavi sonrası istatistiksel olarak anlamlı düzelme mevcuttu ve ilaçlar arasında istatistiksel olarak anlamlı bir fark yoktu.

Sonuç: Bu çalıșmada, yoğun bakıma ihtiyaç duymayan Koronavirüs hastalığı 2019 hastalarında hidroksiklorokine kıyasla tedavi sonrası laboratuvar ve bilgisayarlı tomografi bulgularındaki değișiklikler açısından favipiravirin anlamlı bir üstünlügü bulunamamıștır.

Anahtar Kelimeler: Șiddetli Akut Solunum Sendromu Koronavirüs 2, Favipiravir, Bilgisayarlı Tomografi, Tomografi Skoru

\section{Abstract}

\section{Medical Treatment in Covid-19: Changes in Post-treatment Laboratory Results and CT Findings}

Objective: Today, the symptoms, imaging features and laboratory findings of the disease are known, but the treatment of the Coronavirus disease 2019 has not been clarified. In this study, we aim to investigate the efficacy of favipiravir in patients who do not need invasive mechanical ventilation, by examining the post-treatment laboratory and computed tomography findings compared to the hydroxychloroquine which removed from the treatment guide.

Methods: In our study, 49 patients diagnosed with Coronavirus disease 2019 and treated with hydroxychloroquine and favipiravir were examined. The patients were divided into 3 groups according to their treatment modalities. The changes in the pre- and post-treatment laboratory findings and computed tomography imaging of the patients in these 3 groups were examined.

Results:There was no statistically significant difference between the rates and types of lesion patterns observed on thorax computed tomography in the groups. The most common lesion pattern in each group was the presence of ground glass opacity + consolidation in 18 patients (81.8\%) in the hydroxychloroquine group, 7 patients (70\%) in the favipiravir group and 10 patients (58.8\%) in the hydroxychloroquine + favipiravir group. In all 3 groups, there was a statistically significant improvement in C-reactive protein, ferritin, fibrinogen values and computed tomography scores after treatment and there was no statistically significant difference between drugs.

Conclusion: In this study, we found no significant superiority of favipiravir in terms of changes in laboratory and computed tomography findings after treatment in Covid-19 patients who do not need intensive care compared to hydroxychloroquine.

Keywords: Severe Acute Respiratory Syndrome Coronavirus 2; Favipiravir; Computed Tomography; Tomography Score

Nasıl Atıf Yapmalı: Korkmaz I, Dikmen N. Medical Treatment in Covid-19: Changes in Post-treatment Laboratory Results and CT Findings. MKÜ Tıp Dergisi. 2021;12(44):191198. https://doi.org/10.17944/mkutfd.940622 


\section{INTRODUCTION}

Since the World Health Organization declared it as a pandemic in March 2020, the total number of cases due to Coronavirus disease 2019 (COVID-19) has reached 107.838.255 and total deaths have reached 2.373.398 (1). As COVID-19 has become a global threat, intensive investigations have been conducted for the transmission routes, clinical symptoms, imaging findings, and treatment of the disease, and many clinical studies have been carried out.

Clinical symptoms of the disease include symptoms such as fever, cough, dyspnea, myalgia, headache, diarrhea, loss of taste and smell, which are generally seen in other viral infections $(2,3)$. In the studies conducted, in laboratory tests, various biomarkers such as lymphocyte count, neutrophil-lymphocyte ratio, CRP (C-reactive protein), troponin T, D-dimer, lactate dehydrogenase, procalcitonin, interleukin-6, and ferritin found useful as predictor of mortality in disease progression in COVID-19 $(4,5)$.

Due to the false negativity rates that are originating from reasons such as kit sensitivity, faulty sampling techniques, differences in viral load, of reverse transcriptase polymerase chain reaction (RT-PCR) test, which is the gold standard in the diagnosis of the disease, imaging techniques have been used to aid the differential diagnosis, and in some studies, it has been reported that the diagnostic sensitivity of thoracic computed tomography $(\mathrm{CT})$ was found to be higher than the RT-PCR test (6). Common CT findings of Covid-19 pneumonia are mostly ground-glass opacities and consolidations and accompanying findings such as crazy paving pattern, air bubble sign, halo and inverted halo sign, airway changes $(7,8,9,10)$.

Today, with examinations and clinical studies, the symptoms, imaging features, and laboratory findings of the disease are known, however, the treatment of the disease has not been clarified. Although hundreds of clinical studies have been and are being conducted on agents such as remdesivir, favipiravir (FVP), lopinavir, interferon-alpha and steroids (11, 12), data on the efficacy of these agents are still limited. As a result of numerous studies and clinical trials conducted on the use of hydroxychloroquine (HCQ), after the World Health Organization (WHO) announced that hydroxychloroquine does not cause a decrease in the mortality rates of hospitalized COVID-19 patients compared to standard care (13), HCQ has recently removed in Turkey from the Ministry of Health Adult Patient treatment guideline (14).

Severe acute respiratory syndrome coronavirus(SARS-CoV-2), a single-stranded RNA-enveloped virus, targets cells through the viral structural spike (S) protein that binds to the angiotensin converting enzyme 2(ACE2) receptor. The virus particle follows the receptor bind, using host cell receptors and endosomes to enter cells, and host type 2 trans- membrane serine protease facilitates cell entry through the $S$ protein. Once entered inside the cell, viral polyproteins encoding the replicase-transcriptase complex are synthesized. The virus then synthesizes RNA through RNA-dependent RNA polymerase. This viral life cycle provides potential targets for drug therapy (15).

The aim of this study is to investigate the efficacy of FVP in patients who do not need invasive mechanical ventilation, by examining the post-treatment laboratory and CT findings compared to the HCQ which removed from the treatment guide.

\section{MATERIALS AND METHODS}

\section{Patients}

Clinical symptoms at the time of hospitalization and laboratory findings ( white blood cell, D-dimer, procalcitonin, ferritin, C-reactive protein, fibrinogen) recorded in our system of patients who applied to our hospital with the suspicion of Covid-19 between March 2020 and August 2020, who had positive RT-PCR tests performed with nasal and nasopharyngeal sampling, who were hospitalized in the isolated service of our hospital and who did not require invasive mechanical ventilation with the diagnosis of Covid-19 infection were retrospectively evaluated and recorded.

Patients who received treatment other than FVP and HCQ, patients who refused treatment, patients who did not have thoracic CT imaging, those who developed drug allergy, pregnant women and patients younger than 18 years were excluded from the study. As a result, a total of 49 patients who were hospitalized in the isolated service with the diagnosis of Covid-19 and who were given FVP and HCQ treatment at the appropriate time and at the appropriate dose according to the Ministry of Health Adult Patient Treatment Guidelines were included in the study. The treatment regimen was given to HCQ recipients at 200mg twice daily for five or ten days, depending on the patient's clinical condition; FVP recipients were given $1600 \mathrm{mg}$ twice a day as a loading dose on the first day and $600 \mathrm{mg}$ twice a day as a maintenance dose for five or ten days, depending on the clinical condition of the patient (16).

Among the patients in our study, antibiotic treatment was given to patients with suspected secondary bacterial infection, nasal / oronasal oxygen support in patients with hypoxia, and fluid support to patients with poor oral intake.

Laboratory and thoracic CT findings of the patients before treatment and changes in these findings after treatment were examined. The patients were classified into three groups according to their treatment modalities that were those using FVP, those using HCQ, and those using HCQ + FVP. The changes in the pre- and post-treatment laboratory findings and CT 
imaging of the patients in these three groups were examined.

\section{Laboratory Findings}

The values at the time of hospitalization of white blood cell, D-dimer, procalcitonin, ferritin, C-reactive protein, and fibrinogen, which are thought to be related to the severity of the disease, and the values in the first month of control were recorded and compared. In groups, pre- and post-treatment values of these laboratory markers were calculated as mean \pm sd and evaluated statistically.

\section{CT Protocol}

CT scans were performed in the supine position using either Hitachi Eclos 16 ( $5 \mathrm{~mm}$ slice thickness, $120 \mathrm{kV}, 75 \mathrm{mAs}$ ) or 64-slice Toshiba Aquilion (5 mm slice thickness, $120 \mathrm{kV}$, $25 \mathrm{mAs}$ ) units. Images were acquired in the supine position during deep inspiration. Multiplanar images were acquired using the multiplanar reforming (MPR) technique on a workstation.

\section{Image Analysis}

Thoracic CT images of all patients included in the study, which were acquired at the time of diagnosis before treatment and in the first and second months after treatment, were examined by a single radiologist with 10 years of experience.

Images were examined for lesion patterns that can be seen in Covid-19 pneumonia, such as pure ground-glass opacity, ground-glass opacity and consolidation association, consolidation, crazy paving pattern, air bubble sign, halo sign, inverted halo sign, airway changes, and fibrous band formations. A semi-quantitative scoring system was used to quantitatively estimate the lung distribution of these lesion patterns according to the affected area $(17,18)$. Each lobe of the lung (upper right, middle right, lower right, upper left, and lower left) was scored visually on a numerical scale from 0 to 5 . It was scored as ' 0 ' for no involvement, ' 1 ' for less than $5 \%$ involvement, ' 2 ' for 5\% - 25\% involvement, ' 3 ' for 26\% - $49 \%$ involvement, ' 4 ' for $50 \%-75 \%$ involvement and ' 5 ' for the involvement over $75 \%$. As a result, the total CT Score of each patient, varying between 0 and 25, was calculated in the Thoracic $\mathrm{CT}$ examinations obtained before and after treatment. The changes in the total CT Scores of the patients after the treatment were examined. In groups, CT scores were calculated as mean \pm sd and evaluated statistically.

In addition, distribution patterns of lesions in the lung tissue were classified as peripheral (outer third of the lung), central (inner two thirds of the lung) or peripheral + central localization.

\section{Statistical Analysis}

In our study, the data were analyzed using the SPSS 21 software with 95\% confidence. Quantitative data were defined as mean \pm standard deviation. After evaluating the normality for continuous variables with the Shapiro Wilk test, Paired-t, Wilcoxon and Kruskal Wallis tests were used. The Mann Whitney $U$ test with Bonferroni correction $(p=0.05 / 3=0.016)$ was used for post-hoc analysis for three groups. Chi-Square tests were used for categorical variables. As the statistical significance limit, 0.05 was accepted.

\section{RESULTS}

Of the patients included in the study, 18 (36.7\%) were female and 31 (63.3\%) were male. The mean age of all patients was $55.8 \pm 14.7$ and the age range was between $25-93$. When the distribution according to the groups was examined, there were 22 patients (8 females, 14 males, mean age: $55.2 \pm 17.1$ ) in the HCQ group, 10 patients (4 females, 6 males, mean age: $61.6 \pm 10.8$ years) in the FVP group, and 17 patients (6 females, 11 males, mean age: $53.2 \pm 13.1$ years) in the HCQ + FVP group. There was no statistically significant difference between the patient ages in the groups $(p=0.155)$.

\section{Clinical and Laboratory Findings}

The most common clinical symptoms seen in all patients were fever, cough, and myalgia, in order of frequency. In addition to these complaints, there were less frequently headache, dyspnea, and loss of taste and smell.

Of the patients included in the study, there were comorbid diseases such as hypertension in 18 (36.7\%), diabetes in 16 (32.7), asthma in 2 (4.1\%), coronary artery disease in 4 (8.2), chronic renal failure in 2 (4.1\%), arrhythmia in 1 (2\%) and cancer in $1(2 \%)$.

When the changes in laboratory findings before and after treatment according to the groups were examined (Table 1); there was no significant improvement observed in the white blood cell count in the groups. In the FVP group, there was no significant decrease in procalcitonin value, which is an indicator of bacterial infection; however, pre-treatment values of procalcitonin were already within normal limits in all groups. Although the decrease in D-dimer value in the FVP group was not statistically significant, it was not as high as the other two groups before treatment compared to the other groups. There was a statistically significant improvement in CRP, ferritin and fibrinogen values after treatment in all groups.

\section{Imaging Findings}

Consistent with the literature, the most common lesion patterns observed in thoracic $\mathrm{CT}$ examinations of the patients were ground-glass opacity in 8 patients (16.3\%), ground-glass opacity + consolidation in 35 patients (71.4\%), and pure consolidation in 5 patients $(10 \%, 2)$. Apart from these, 4 patients had crazy paving pattern (8.2\%), 17 patients had fibrotic band formations (34.7\%), and 1 patient had a curvilinear line (2\%). There was no statistically significant difference between the 
Table 1: Changes in laboratory findings before and after treatment in the groups

\begin{tabular}{|c|c|c|c|c|}
\hline Parameter & & $\mathrm{HCQ}(\mathrm{n}=22)$ & $\operatorname{FVP}(n=10)$ & $\mathrm{HCQ}+\mathrm{FVP}(n=17)$ \\
\hline \multirow{3}{*}{ WBCS } & $\begin{array}{c}\text { before } \\
\text { treatment }\end{array}$ & $7851.36 \pm 5962.26$ & $\begin{array}{c}6790.00 \pm \\
1839.40\end{array}$ & $7359.41 \pm 2090.98$ \\
\hline & $\begin{array}{c}\text { after } \\
\text { treatment }\end{array}$ & $7060.90 \pm 2047.67$ & $7437.00 \pm 1779.12$ & $7708.24 \pm 1324.45$ \\
\hline & $\mathrm{p}$ & 0.833 & 0.382 & 0.47 \\
\hline \multirow{3}{*}{ D dimer } & $\begin{array}{c}\text { before } \\
\text { treatment }\end{array}$ & $1582.14 \pm 1980.65$ & $842.70 \pm 462.67$ & $1599.52 \pm 2345.91$ \\
\hline & $\begin{array}{c}\text { after } \\
\text { treatment }\end{array}$ & $454.81 \pm 302.72$ & $521.80 \pm 233.38$ & $471.94 \pm 228.98$ \\
\hline & $\mathrm{p}$ & $<0.001$ & 0.076 & 0.004 \\
\hline \multirow{3}{*}{ Procalcitonin } & $\begin{array}{c}\text { before } \\
\text { treatment }\end{array}$ & $0.07 \pm 0.081$ & $0.03 \pm 0.03$ & $0.09 \pm 0.20$ \\
\hline & $\begin{array}{c}\text { after } \\
\text { treatment }\end{array}$ & $0.02 \pm 0.027$ & $0.02 \pm 0.02$ & $0.02 \pm 0.02$ \\
\hline & $p$ & 0.001 & 0.292 & 0.01 \\
\hline \multirow{3}{*}{ Ferritin } & $\begin{array}{c}\text { before } \\
\text { treatment }\end{array}$ & $400.12 \pm 579.12$ & $532.52 \pm 358.35$ & $365.22 \pm 375.91$ \\
\hline & $\begin{array}{c}\text { after } \\
\text { treatment }\end{array}$ & $105.27 \pm 115.48$ & $151.53 \pm 105.13$ & $77.92 \pm 76.46$ \\
\hline & $p$ & $<0.001$ & 0.004 & $<0.001$ \\
\hline \multirow{3}{*}{ CRP } & $\begin{array}{c}\text { before } \\
\text { treatment }\end{array}$ & $46.37 \pm 60.94$ & $75.05 \pm 38.78$ & $52.85 \pm 49.17$ \\
\hline & $\begin{array}{c}\text { after } \\
\text { treatment }\end{array}$ & $4.50 \pm 2.35$ & $8.01 \pm 7.90$ & $4.52 \pm 3.16$ \\
\hline & $\mathrm{p}$ & $<0.001$ & 0.005 & 0.001 \\
\hline \multirow{3}{*}{ Fibrinogen } & $\begin{array}{c}\text { before } \\
\text { treatment }\end{array}$ & $454.54 \pm 238.69$ & $545.90 \pm 145.89$ & $513.23 \pm 147.22$ \\
\hline & $\begin{array}{c}\text { after } \\
\text { treatment }\end{array}$ & $333.18 \pm 101.42$ & $306.80 \pm 123.26$ & $356.82 \pm 70.95$ \\
\hline & $\mathrm{p}$ & 0.005 & $<0.001$ & $<0.001$ \\
\hline
\end{tabular}

Data are reported as mean \pm SD.

HCQ: Hydroxychloroquine. FVP: Favipiravir. WBCs: White blood cells. CRP: C-reactive protein

rates and types of lesion patterns observed in the groups. The most common lesion pattern in each group was observed to be the presence of ground-glass opacity + consolidation in 18 patients (81.8\%) in the HCQ group, in 7 patients (70\%) in the FVP group, and in 10 patients (58.8\%) in the HCQ + FVP group (Figure 1).

In the examination of the distribution patterns of the lesions in the lung tissue, there was peripheral distribution in $21(42.9 \%)$ patients and peripheral + central distribution in $28(57.1 \%)$ patients. Pure central distribution was not detected in any of the patients.
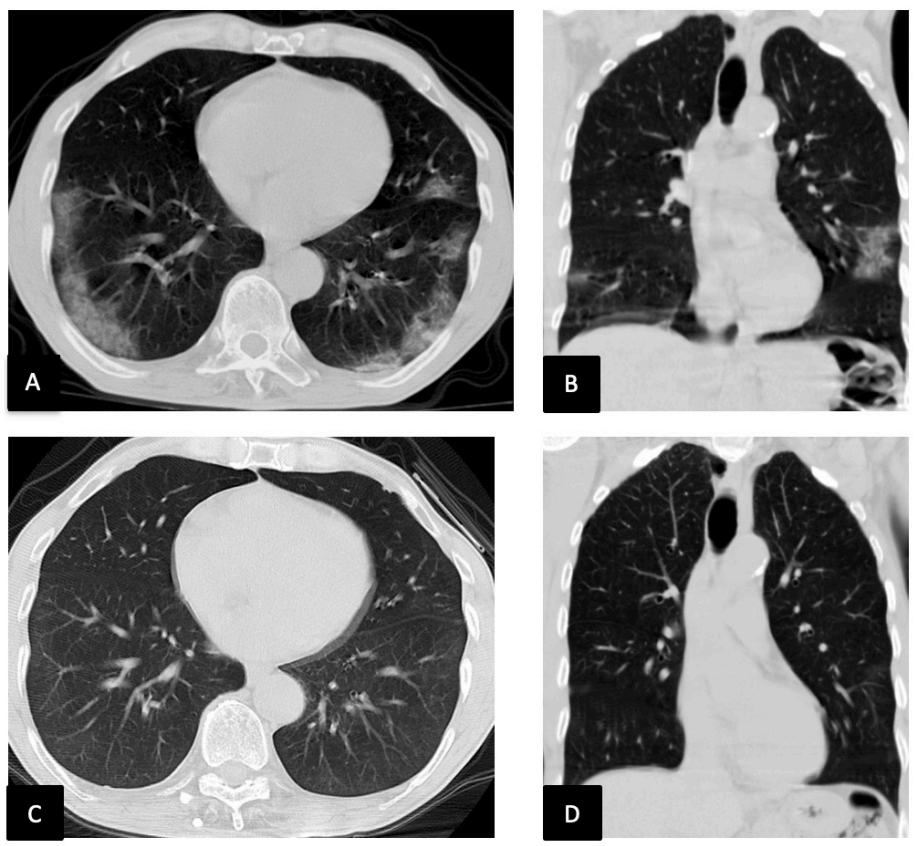

Figure 1: In a patient in the HCQ group, pre-treatment thorax CT (total score $=6$ ) images show the association of peripherally located ground glass opacity and consolidation in both lungs (A, B). In the post-treatment images of the same patient (total score $=2$ ), weak ground-glass opacities are observed in sections passing through the same level $(\mathbf{C}, \mathbf{D})$.
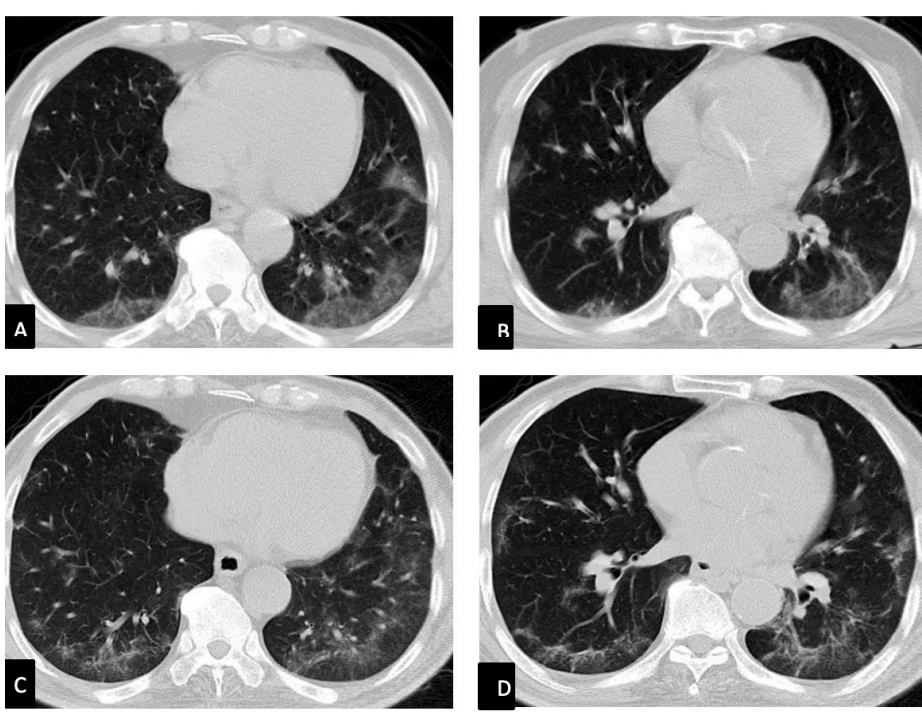

Figure 2: In the patient in the FVP group, pre-treatment thorax CT (total score $=13$ ), bilateral peripheral ground glass opacities and mild prominence in vascular structures are observed in sections passing through different levels (A, B). Post-treatment images of the same patient (total score $=12$ ) show a decrease in the amount of ground-glass opacity in the same level sections, but the involvement continues. There are also newly developed fibrotic band formations (C, D).

There was a statistically significant improvement in the pre-treatment CT score and the post-treatment CT score change in all three groups (Table 2). When drug efficacy was evaluated, there was a more significant decrease in post-treatment CT scores in those who received HCQ than those who received FVP $(p=0.02)$. It was thought that this might be due to the patients' clinics being more severe in the pandemic 
phase in which FVP was started to be received and it would be meaningful to evaluate late CTs due to radiological late recovery (Figure 2).

Table 2: CT seore changes of the groups after treatment

\begin{tabular}{|c|c|c|c|}
\hline & $\begin{array}{c}\text { HCQ } \\
(\mathbf{n}=22)\end{array}$ & $\begin{array}{c}\text { FVP } \\
(\mathbf{n}=10)\end{array}$ & $\begin{array}{c}\text { HCQ }+ \text { FVP } \\
(\mathbf{n}=17)\end{array}$ \\
\hline Before treatment & $8.79 \pm 5.89$ & $10.74 \pm 5.96$ & $10.23 \pm 6.41$ \\
\hline After treatment & $3.56 \pm 4.28$ & $6.07 \pm 5.23$ & $4.35 \pm 4.88$ \\
\hline $\mathbf{p}$ & $<0.001$ & $<0.001$ & $<0.001$ \\
\hline
\end{tabular}

Data are reported as mean \pm SD.

HCQ: Hydroxychloroquine, FVP: Favipiravir

\section{DISCUSSION}

In this study, we examined the HCQ, an aminoquinoline with immunomodulating effect, and FVP, an RNA polymerase inhibitor, in terms of their effects in the treatment of 49 patients hospitalized with new coronavirus (2019-nCoV) infection. Although more than 1 year has passed since the onset of the Covid-19 pandemic, no treatment agent has been proven to be effective in Covid-19 disease to date.

CQ (chloroquine) and HCQ are aminoquinolines that have been used to treat malaria and autoimmune diseases for over 50 years. In addition, these two drugs have immunomodulatory effects that allow them to be used in the treatment of autoimmune conditions such as systemic lupus erythematosus and rheumatoid arthritis. While inhibiting certain cellular functions and molecular pathways regarding the immune activation, CQ analogues can penetrate into acidic organelles and be concentrated, leading to inhibition of endosome traffic by causing high intra-vesicular $\mathrm{pH}$, and preventing viral fusion into the cell. This mechanism has become these drugs' potential role in the treatment of COVID-19. However, apart from these efficacy discussions, there are growing concerns about its safety. Both drugs have been independently shown to increase the risk of QT interval prolongation, drug-induced torsade's de pointes, and drug-induced sudden cardiac death (19). FVP is an antiviral agent that selectively and strongly inhibits RNA-dependent RNA polymerase (RdRp) of RNA viruses. It has been shown to be effective in the treatment of influenza and, to some extent, in the treatment of Ebola virus disease (19).

As a result of studies and controlled trials for HCQ and FVP, different opinions have been raised about the sufficiency and efficacy of these drugs. In the clinical studies conducted in the early stages of the pandemic, it has been reported that HCQ is a safe and successful anti-inflammatory agent that is widely used in autoimmune diseases and can significantly reduce the production of cytokines and especially pro-inflammatory factors, apart from its direct antiviral activity (20). A study of
36 patients (20 in the HCQ group and 16 in the control group) has reported increased virological clearance with oral HCQ intake every 8 hours compared to control patients receiving standard supportive therapy. The authors have also reported that the addition of azithromycin to HCQ in 6 patients resulted in numerically superior viral clearance $(6 / 6,100 \%)$ compared to HCQ (8/14, 57\%) monotherapy (15). A retrospective multi-center study conducted in June 2020 has reported that HCQ with or without azithromycin did not reduce mortality, ventilation rate, or hospital stay (21). In addition, there are many studies in the literature suggesting that HCQ is effective in the treatment or, on the contrary, has no significant effect on mortality and ventilation rates $(22,23,24,25,26)$. In a review study published in 2021, it was emphasized that despite some early positive results, hydroxychloroquine does not affect the overall mortality, ventilation initiation and length of stay in hospitalized patients (27).

Similarly, there are different opinions for the FVP treatment in Covid-19 disease, and the treatment efficiency of FVP has not been clarified. There are studies in the literature reporting that FVP reduces viral clearance and increases healing rates (28), along with studies (15) presenting findings that it has no significant effect on clinical improvement.

In the examination of laboratory markers in the groups, there was a statistically significant improvement in the values of ferritin, CRP, and fibrinogen pre- and post-treatment in all three groups, and there was no significant difference between the groups.

Although there are a limited number of studies comparing HCQ and FVP in the literature, in a study conducted by Dabbous HM et al, laboratory parameters have been compared in two patient groups receiving CQ and FVP treatment (29). In this study, there was no significant difference between laboratory parameters in both groups, as in our study. In the study, it has been reported that the duration of hospital stay was shorter in the group receiving FVP and that none of the patients in this group required mechanical ventilation; however, these findings were not statistically significant. In addition, in this study, it has been reported that the factors significantly associated with mortality were the patient's age and CRP level ( $p=0.045$ and 0.019 , respectively). In our study, there was a statistically significant decrease in CRP levels after treatment in all three groups, and there was no statistically significant difference between drugs.

In another study, which was in the prepress stage and 
whose peer review was not completed (30), groups who received HCQ + FVP and HCQ treatment have been examined and a statistically significant improvement in CRP and ferritin values, which are known as poor prognostic factors, has been reported in patients using FVP. In our study, there was a statistically significant decrease in CRP and ferritin levels in all three groups, and there was no statistically significant difference between drugs.

In the literature, there are no studies conducted and interpreted in terms of the effect of HCQ on radiological healing, and an evaluation was made in this respect in our study. In studies on the radiological healing effect of FVP, faster radiological recovery has been reported in patients who received FVP for control groups (24); however, larger confirmatory studies are required. In our study, since time was required for radiological recovery, we performed CT controls of the patients 1 month after the first CT date (31). In the pre- and post-treatment evaluations made by considering the CT scores, there was a statistically significant $(p<0.001)$ improvement in terms of radiological improvement in all three groups.

Considering the improvement in laboratory and CT findings after treatment in patients receiving HCQ, which has been shown to be ineffective in randomized studies, the improvement may be due to standard care, conservative treatment and adequate respiratory support (13, 32).

There were some limitations in our study. First of all, the number of cases in our study was limited. Second, we did not have a placebo control group that was not given any medication. In our study, the treatment durations of all patients were not the same, because we had patients who were discharged earlier due to clinical improvement. Fourth, the effects of drugs in the severely ill group that were intubated were not examined. Finally, in our study, no comment was made in terms of the correlation between viral titer and clinical prognosis.

\section{CONCLUSION}

Despite the known possible side effects of HCQ and FVP and the fact that controversial results in terms of efficacy have been reported in the studies conducted, there are protocols that recommend and implement the use of both agents. In this study, we found no significant superiority of FVP in terms of changes in laboratory and CT findings after treatment in Covid-19 patients who do not need intensive care compared to HCQ. Large-scale, membered and specially designed randomized clinical trials are still needed for the effectiveness of FVP in Covid-19 disease.

\section{ACKNOWLEDGEMENT}

Peer-Review

Externally Peer Reviewed

Conflict of Interest

All authors have contributed to, read and approved the final manuscript for submission. There are no conflicts of interest to declare.

Financial Support

The Authors report no financial support regarding content of this article.

\section{Ethical Declaration}

This retrospective study was approved by the local ethics committee and the requirement for informed consent was waived (11/12/2020, meeting no. 13, decision no 27). The study protocol complies with the ethics of the 1975 Declaration of Helsinki, pre-approved by the institution's human research committee.

\section{REFERENCES}

1. Weekly Operational Update on COVID-19 13 February 2021(cited 2021 Feb 15). Available from: https://www.who.int/ publications/m/item/weekly-operational-update-on-covid19---13-february-2021

2. Kanne JP. Chest CT findings in 2019 novel coronavirus (2019$\mathrm{nCoV}$ ) infections from Wuhan, China: key points for the radiologist. Radiology 2020;295:16-17. DOI: https://doi. org/10.1148/radiol.2020200241

3. Li LQ, Huang T, Wang YQ, Wang ZP, Liang Y, Huang T, et al COVID-19 patients' clinical characteristics, discharge rate, and fatality rate of meta-analysis. J Med Virol 2020;92:577-83. https://doi.org/10.1002/jmv.25757

4. Fang FC, Naccache SN, Greninger AL. The laboratory diagnosis of coronavirus disease 2019-frequently asked questions. Clin Infect Dis 2020;71:2996-001. https://doi.org/10.1093/cid/ ciaa742

5. Ji P, Zhu J, Zhong Z, Li H, Pang J, Li B, et al. Association of elevated inflammatory markers and severe COVID-19: A metaanalysis. Medicine 2020:99(47). http://dx.doi.org/10.1097/ MD.0000000000023315

6. Fang $\mathrm{Y}$, Zhang $\mathrm{H}$, Xie J, Lin M, Ying L, Pang P, et al. Sensitivity of Chest CT for COVID-19: Comparison to RT-PCR. Radiology 2020;296:115-17. https://doi.org/10.1148/radiol.202020 0432

7. Ye Z, Zhang Y, Wang Y, Huang Z, Song B. Chest CT manifestations of new coronavirus disease 2019 (COVID-19): a pictorial review. Eur Radiol 2020;30:4381-389. https://doi. org/10.1007/s00330-020-06801-0 
8. Jin YH, Cai L, Cheng ZS, Cheng H, Deng T, Fan YP, et al. A rapid advice guideline for the diagnosis and treatment of 2019 novel coronavirus (2019-nCoV) infected pneumonia (standard version). Military Med Res 2020;7:1-23. https://doi. org/10.1186/s40779-020-0233-6

9. Akçay \$, Özlü T, Yılmaz A. Radiological approaches to COVID-19 pneumonia. Turk J Med Sci 2020;50:604-10. https:// doi.org/10.3906/sag-2004-160

10. Yoon SH, Lee KH, Kim JY, Lee YK, Ko H, Kim KH, et al. Chest radiographic and CT findings of the 2019 novel coronavirus disease (COVID-19): analysis of ninepatients treated in Korea. Korean J Radiol 2020;21:494-00. https://doi.org/10.3348/ kjr.2020.0132

11. Wiersinga WJ, Rhodes A, Cheng AC, Peacock SJ, Prescott HC. Pathophysiology, transmission, diagnosis, and treatment of coronavirus disease 2019 (COVID-19). JAMA 2020;324:782-93. https://doi.org/10.1001/jama.2020.12839

12. Barlow A, Landolf KM, Barlow B. Review of emerging pharmacotherapy for the treatment of coronavirusdDisease 2019. Pharmacotherapy 2020;40:416-37. https://doi. org/10.1002/phar.2398

13. Coronavirus disease (COVID-19): Solidarity Trial and hydroxychloroquine (cited 2020 Sep 1). Available from: https://www.who.int/news-room/q-a-detail/coronavirusdisease-covid-19-hydroxychloroquine

14. T.C. Sağlık Bakanlığı COVID-19 Erișkin Hasta Tedavisi (cited 2021 May 17). Avaible from: https://covid19.saglik.gov.tr/ Eklenti/40719/0/covid-19rehberieriskinhastayonetimivetedav ipdf.pdf

15. Sanders JM, Monogue ML, Jodlowski TZ, Cutrell JB. Pharmacologic treatments for coronavirus disease 2019 (COVID-19). JAMA 2020;323:1824-836. https://doi.org/ 10.1001/jama.2020.6019

16. T.C. Sağlık Bakanlığı COVID-19 Erișkin Hasta Tedavisi (cited 2020 Apr 13). Avaible from: https://www.ekmud.org.tr/files/ uploads/files/COVID-19_Rehberi-6.pdf

17. Pan F, Ye T, Sun P, Gui S, Liang B, Li L, et al. Time course of lung changes at chest $\mathrm{CT}$ during recovery from coronavirus disease 2019 (COVID-19). Radiology 2020;295:715-21. https:// doi.org/10.1148/radiol.2020200370

18. Francone F, Lafrate F, Masci GM, Coco S, Cilia F, Manganaro L, et al. Chest CT score in COVID-19 patients: correlation with disease severity and short-term prognosis. Eur Radiol 2020;30:6808-817. https://doi.org/10.1007/s00330-02007033-y

19. Yavuz SȘ, Ünal S. Antiviral treatment of Covid-19. . Turk J Med Sci 2020;50:611-19. https://doi.org/10.3906/sag-2004-145
20. Liu J, Cao R, Xu M, Wang X, Zhang $\mathrm{H}$, $\mathrm{Hu} \mathrm{H}$, et al. Hydroxychloroquine, a less toxic derivative of chloroquine, is effective in inhibiting SARS-CoV-2 infection in vitro. Cell Discov 2020;6:1-4. https://doi.org/10.1038/s41421-020-0156-0

21. Magagnoli J, Narendran S, Pereira F, Cummings TH, Hardin JW, Sutton SS, et al. Outcomes of hydroxychloroquine usage in United States veterans hospitalized with Covid-19. Med 2020;1: 114-27. https://doi.org/10.1016/j.medj.2020.06.001

22. Keyaerts E, Li S, Vijgen L, Rysman E, Verbeeck J, Ranst MV, et al. Antiviral activity of chloroquine against human coronavirus OC43 infection in newborn mice. Antimicrob Agents Chemother 2009;53:3416-421. https://doi.org/10.1128/ AAC.01509-08

23. Barnard DL, Day CW, Bailey K, Heiner M, Montgomery $\mathrm{R}$, Lauridsen $\mathrm{L}$, et al. Evaluation of immunomodulators, interferons and known in vitro SARS-coV inhibitors for inhibition of SARS-coV replication in BALB/C mice. Antivir Chem Chemother 2006;17: 275-84.

24. Vincent MJ, Bergeron E, Benjannet S, Erickson BR, Rollin PE, Ksiazek TG, et al. Chloroquine is a potent inhibitor of SARS coronavirus infection and spread. Virol J 2005;2:1-10. https:// doi.org/10.1186/1743-422X-2-69

25. Rosenberg ES, Dufort EM, Udo T, Wilberschied LA, Kumar J, Tesoriero J, et al. Association of treatment with Hydroxychloroquine or Azithromycin with in-hospital mortality in patients with COVID-19 in NewYork State. JAMA 2020;323:2493-502. https://doi.org/10.1001/jama.2020.8630

26. Geleris J, Sun Y, Platt J, Zucker J, Baldwin M, Hripcsak G, et al. Observational study of Hydroxychloroquine in hospitalized patients with Covid-19. N Engl J Med 2020;382:2411-418. https://doi.org/10.1056/NEJMoa2012410

27. Gasmi A, Peana M, Noor S, Lysiuk R, Menzel A, Benahmed AG, et al. Chloroquine and hydroxychloroquine in the treatment of COVID-19:the never-ending story. Appl Microbiol Biotechnol 2021;105:1333-343. https://doi.org/10.1007/s00253-021$11094-$

28. Cai Q, Yang M, Liu D, Chen J, Shu D, Xia J, et al. Experimental treatment with Favipiravir for COVID-19: an open-label control study. Engineering 2020;6:1192-198. http://dx.doi. org/10.1016/j.eng.2020.03.007

29. Dabbous HM, Abd-Elsalam S, El-Sayed M, Sherief AF, Ebeid FFS, Abd-El Ghafar MS, et al. Efficacy of favipiravir in COVID-19 treatment: a multi-center randomized study. Arch Virol 2021;166:949-54. https://doi.org/10.1007/s00705-021-049569

30. Uçan A, Çerçi P, Efe S, Akgün H, Özmen A, Yağmuroğlu A, et al. Benefits of treatment with Favipiravir in hospitalized patients for COVID-19: a retrospective observational case-control study. 2021. https://doi.org/10.21203/rs.3.rs-175340/v1 
31. Önol S, Karakacıoğlu D, Bayraktarlı RY. COVID-19 pnömonisinde radyolojik takip (zamansal değișim). Savaş R, editör. Radyoloji ve COVID-19. 1. Baskı. Ankara: Türkiye Klinikleri; 2020. P.57-63
32. Raymondi DM, Hernandez L. Supportive treatment of COVID 19 patients with mild respiratory failure in a primary hospital. Med Clin 2020;155(5):222-24. https://doi. org/10.1101/2020.02.10.20021832 